\title{
Nordic Higher Education in Flux: System Evolution and Reform Trajectories
}

\author{
Rómulo Pinbeiro, Timo Aarrevaara, \\ Laila Nordstrand Berg, Tatiana Fumasoli, \\ Lars Geschwind, Hanne Foss Hansen, Helge Hernes, \\ Jussi Kivistö, Jonas Krog Lind, Anu Lyytinen, \\ Elias Pekkola, Kirsi Pulkkinen, Bjørn Stensaker, \\ and Johan Söderlind
}

Helge Hernes passed away in the Fall of 2018.

\footnotetext{
R. Pinheiro $\bullet H$. Hernes

Department of Political Science \& Management, University of Agder, Kristiansand, Norway

e-mail: romulo.m.pinheiro@uia.no

T. Aarrevaara • K. Pulkkinen $(\square)$

Faculty of Social Sciences, University of Lapland, Rovaniemi, Finland e-mail: timo.aarrevaara@ulapland.fi; kirsi.pulkkinen@ulapland.fi

L. N. Berg

Department of Social Science, Western Norway University of Applied Sciences, Sogndal, Norway e-mail: laila.nordstrand.berg@hvl.no
} 


\title{
INTRODUCTION
}

Higher education (HE) in the Nordic countries has experienced continuous change in the last three decades. This has partially been a result of the increased number of enrolled students, but it is also a result of the influence of larger societal trends, such as urbanisation, digitalisation, and the importance attributed to innovation and global competition. Governmental reforms have placed an emphasis on quality, excellence, efficiency, and accountability, and have led to significant changes in the internal fabric of publicly funded universities. At the system level, the traditional binary divide characterising higher education throughout the Nordic region has also been affected. In some countries, such as Norway, the general trend has been convergence towards a unitary model based on comprehensive research-intensive universities, whereas other countries (e.g., Finland) still exhibit policy commitments towards maintaining horizontal diversity, with different providers undertaking specific functions.

Given their geographical features, regional dimensions also play an important role; however, these have also been adapting to the new realities facing localities and regions beyond the largest urban areas. As is the case with other countries' higher education systems, the influence of marketbased models has been felt in the Nordics, and new public management

\author{
T. Fumasoli \\ UCL Institute of Education, University College London, \\ London, United Kingdom \\ e-mail: t.fumasoli@ucl.ac.uk \\ L. Geschwind • J. Söderlind \\ School of Industrial Engineering and Management, KTH Royal Institute of \\ Technology, Stockholm, Sweden \\ e-mail: larsges@kth.se; johanso2@kth.se \\ H. F. Hansen • J. K. Lind \\ Department of Political Science, University of Copenhagen, \\ Copenhagen, Denmark \\ e-mail: hfh@ifs.ku.dk; jkl@ifs.ku.dk \\ J. Kivistö • A. Lyytinen • E. Pekkola \\ Faculty of Management and Business, Tampere University, Tampere, Finland \\ e-mail: jussi.kivisto@tuni.fi; anu.lyytinen@tuni.fi; elias.pekkola@tuni.fi \\ B. Stensaker \\ Department of Education, University of Oslo, Oslo, Norway \\ e-mail: bjorn.stensaker@iped.uio.no
}


(NPM)-inspired reforms have resulted in the rise of managerialism focusing on efficiency, performance, and outcome-based assessments. The traditional social contract, which is based on trust between higher education institutions (HEI) and society and is brokered via the state, has gradually yet steadily been replaced by a contractual relationship in which providers are expected to deliver certain pre-determined outcomes in light of agreed-upon input factors (such as people and funding) and performance metrics (such as outputs).

Given their cultural similarities and their shared commitment towards public investments in the realm of welfare and education, the Nordic countries have often been grouped together to encompass the "Nordic model." Yet, beyond the surface, each Nordic country is unique in its own right, and this is reflected in the governance and organisation of their respective national higher education systems. Despite a considerable degree of policy convergence among the Nordic countries, important variations in terms of timing, content, and degree of change can be detected. These national specificities, described in some detail later in this chapter, provide the backdrop for assessing the results of the comparative study that comprise the bulk of this edited volume.

We start by describing how the four national systems included in this study-Denmark, Finland, Norway, and Sweden-are currently organised and structured, illuminating several specific features such as the types and sizes of the institutions, enrolment patterns, performance measures, and funding. The chapter then moves on by providing a snapshot of how higher education systems have evolved historically by shedding light on policy dynamics from the late 1990s to 2013, the baseline period for the comparative study. That being said, and when appropriate, the chapter reflects briefly on key policy developments in the last five years or so (2013-2018 period).

\section{National Higher Education Systems and Recent Policy Dynamics}

\section{Denmark}

\section{Landscape}

Higher education in Denmark is organised into three types of programmes offered by different types of institutions. Short-length programmes are 
offered by business colleges (erbvervsakademier) responsible for vocational training, medium-length bachelor's programmes that train teachers, pedagogues, and social workers are offered by university colleges (professionshøjskoler), and long-length programmes (master's and $\mathrm{PhD}$ programmes) are, in addition to bachelor's programmes, offered by universities. Universities are also responsible for most of the sector's research activity. As indicated above, the empirical focus of this edited volume is solely on the university sector. In 2013, the Danish university landscape consisted of eight universities that enrolled 156,815 students and employed 33,446 staff, as shown in Table 3.1.

As the table shows, the higher education landscape is diverse. Denmark has very large institutions, such as the University of Copenhagen, small institutions, such as RUC, and even tiny institutions, such as ITU. The table also reveals that some institutions, such as CBS, have many students in comparison to the number of staff while other institutions, such as DTU and Aarhus University, have the opposite. Diversity has increased as a result of the merger reform in 2007 (described later) during

Table 3.1 The Danish higher education university landscape, 2013

\begin{tabular}{|c|c|c|c|}
\hline Institution & Type & $\begin{array}{l}\text { Number of enrolled } \\
\text { students }\end{array}$ & $\begin{array}{l}\text { Total number of staff } \\
\left(F T E^{a}\right)\end{array}$ \\
\hline University of Copenhagen & $\begin{array}{l}\text { Multi- } \\
\text { faculty }\end{array}$ & 40,866 & 9652 \\
\hline Aarhus University & $\begin{array}{l}\text { Multi- } \\
\text { faculty }\end{array}$ & 38,169 & 8216 \\
\hline $\begin{array}{l}\text { University of Southern } \\
\text { Denmark (SDU) }\end{array}$ & $\begin{array}{l}\text { Multi- } \\
\text { faculty }\end{array}$ & 22,224 & 3626 \\
\hline Roskilde University (RUC) & $\begin{array}{l}\text { Multi- } \\
\text { faculty }\end{array}$ & 7588 & 1020 \\
\hline Aalborg University & $\begin{array}{l}\text { Multi- } \\
\text { faculty }\end{array}$ & 19,064 & 3379 \\
\hline $\begin{array}{l}\text { Technical University of } \\
\text { Denmark (DTU) }\end{array}$ & $\begin{array}{l}\text { Mono- } \\
\text { faculty }\end{array}$ & 10,196 & 5721 \\
\hline $\begin{array}{l}\text { Copenhagen Business School } \\
\text { (CBS) }\end{array}$ & $\begin{array}{l}\text { Mono- } \\
\text { faculty }\end{array}$ & 16,659 & 1526 \\
\hline $\begin{array}{l}\text { IT University of Copenhagen } \\
\text { (ITU) }\end{array}$ & $\begin{array}{l}\text { Mono- } \\
\text { faculty }\end{array}$ & 1894 & 306 \\
\hline Total & & 156,660 & 33,446 \\
\hline
\end{tabular}

Source: Statistics from Universities Denmark

aFull-time equivalent (FTE) 
which most governmental research institutes were merged into the universities. Due to this reform, there are huge differences in the research intensiveness of these universities today.

\section{System Governance}

The main elements in the governance system of Denmark's university sector are legislation, development contracts (recently re-termed as strategic framework contracts), performance-based funding, accreditation, and dialogue. Universities are so-called self-owing institutions under the auspices of Denmark's Ministry of Higher Education and Science. Boards with external majorities have the overall responsibility of strategically managing the institutions and are accountable to the minister when it comes to the administration of economic resources. Furthermore, these boards appoint the vice-chancellors responsible for the daily management of the universities.

In the Danish university sector, reforms have become part of daily life. Looking back at the last 15 years, the most important policy developments and reforms related to governance have been: the introduction of contract steering in 2000, the governance reform in 2003, the merger reform in 2007 , and the changes in output-based mechanisms for resource allocations in universities. Many of these developments can be traced back to a 2001 report that established a research policy reform agenda. This agenda was, first and foremost, geared towards the need to increase resources for public sector research, reform universities' management structures, strengthen evaluation and quality assurance, and boost $\mathrm{PhD}$ education. In addition, these changes were aimed towards securing critical mass through collaboration and mergers and developing the resource allocation system in a more results-based direction (Aagaard 2012; Hansen 2001; Research Commission 2001).

Since the year 2000, development contracts between Denmark's line ministry and the country's individual universities have been an important element in the governance of the sector. Contracts have lined up important goals and measurable results, but they have not been linked to resource allocations per se. Instead, they have been followed up by the documentation of results in the form of institutional annual reports. In 2015 , "binding goals" were introduced, which line up political goals for the sector as such. The binding goals from 2015 to 2017 were to improve quality of education, increase relevance and collaboration, strengthen internationalisation, and increase social mobility. All Danish universities 
have been committed to helping achieve these goals. The aim of the contract regime is to ensure the responsiveness of the universities to societal political goals.

In 2003, a new university act was introduced. University leaders (vicechancellors, deans, and heads of departments) who in the past had been elected from below (by their peers) were now being appointed from above. Boards with external majorities and elected chairmen among their external members were introduced. According to the law, nominated external board members require experience in the realms of education, research, leadership, organisation, and economics. Academic councils and study boards, in which the majority of members are elected by staff and students, remain important organisational elements. However, under the new governance regime, academic councils have become, primarily, advisory bodies for the deans. The overall intention behind the law was to turn universities into dynamic, strategic actors. In the wake of the reform, an intensive debate arose regarding the consequences of the reduced influence of staff on important decisions. An international evaluation in 2010 argued that the boards had to start taking responsibility to involve staff and students in decision-making processes (Ministry of Science, Technology and Innovation 2009). As a result, the law was changed in 2011 , demanding public universities to adopt internal rules for enhancing staff and also demanding that students be directly involved in governance issues. The universities reacted accordingly by establishing more advisory bodies. With the 2003 act, public universities became self-owned institutions. The meaning of this, however, is unclear. Only a few universities own their buildings. Universities interested in becoming owners of their buildings have hitherto not been allowed to do so. This is one example of a significant restriction of Danish universities' autonomy. Universities were also made responsible for third mission activities. Tasks related to research communications were not new to universities, but the new law stressed the responsibilities of universities in this area.

In 2007, a merger reform was implemented in the university sector. This reform included both inter-university mergers as well as mergers between universities and governmental research institutes (GRIs). A total of 12 universities were reduced to eight, and nine GRIs were merged into the universities. An important overall argument for the mergers was economies of scale, namely, the pooling of finances, knowledge, technical facilities, and buildings to create increased competitiveness. In addition, economies of scale cover the possibilities of saving administrative and per- 
haps even teaching resources (Aagaard et al. 2016). A more specific argument was to strengthen the use of the GRI staff's competencies in the educational programmes of the universities. The merger reform process was politically initiated and coercive, but at the same time, it included a voluntary element. Universities and GRIs could choose with whom they would merge. In retrospect, governance reform can be interpreted as a precondition for merger reform. The new governance structure seemed to be more responsive than the old one. In addition, the new leaders were tempted by the promise of increased resources for research due to the globalisation agreement (as described later in the chapter). At the time of the mergers, the new universities were organised as federal structures, meaning that specific responsibilities remained within the participating institutions. In several Danish universities, post-merger reorganisation processes have been initiated with the aim to develop more unitary structures, whereas former participating institutions ceased to exist due to the adoption of new governance structures.

\section{Funding Structures}

Public resources for Danish universities are allocated through four channels: resources for education, basic resources for research, resources for carrying out tasks for ministries, and resources for research allocated through open competition via research councils and foundations. Over time, the system has become increasingly results-oriented. Resources for education have, since the 1980s, been linked to the number of students who pass their exams. Since 2009, this "taximeter system" has been supplemented by bonuses. Universities receive extra resources if students complete their studies in due time (Regeringen 2010). Among these universities, the allocation of most basic resources for research has been historically determined. Since 2010, however, the allocation of new basic resources for research has been results-based. New resources, which, in most years, have been generated through both cutting back $2 \%$ of the existing resources and using genuine, new, and politically prioritised resources, are allocated to universities according to each university's ability to generate educational resources. These abilities include the number of PhDs awarded by the university, the ability of the university to attract competitive research funds, and the bibliometric indicator measuring the total amount of research production in the university. The latter indicator, based on two quality levels, was developed upon inspiration from Norway. However, the Danish model only re-allocates resources across universities 
within certain scientific fields, not across the main scientific fields as in Norway's model. Very different opinions exist regarding the bibliometric indicator (Dahler-Larsen 2012). Due to its limited re-allocation abilities, this indicator has been characterised as "a lot of fuss about nothing" (Schneider and Aagard 2012). Despite this fact, there is no doubt that the system influences researchers' behaviour, especially within fields where the introduction of the model is followed up by management demands about publication volume or wage bonuses.

Resources for education and basic resources for research are allocated to Danish universities as a lump sum, which gives these institutions strategic manoeuvring room. Danish universities have indeed taken a series of strategic initiatives; however, these are implemented in a context in which departments and faculties fight with one another to obtain their historicallygained resources. Since the merger reform, Danish universities have received additional resources for carrying out certain national tasks. These are allocated based on four-year contracts between specific universities and ministries. If a university does not fulfil its obligations, a ministry may enter into a contract with another actor, such as another university. There are several institutions responsible for allocating competitive resources for research. The most important are the Danish Council for Independent Research (recently renamed the Independent Research Fund Denmark), the Innovation Fund Denmark, which offers resources for strategic research, technology, and innovation, and the Danish National Research Foundation, which funds centres of excellence (for a comparative analysis of Nordic centres of excellence as a research policy initiative, consult Langfeldt et al. 2013). Apart from these main actors, there are several additional programmes within the ministries as well as private foundations, especially within the health sciences field. International research programmes, particularly within the EU (in the context of the European Research Council), are also highly important. In 2012, external research funding in Denmark totalled $28 \%$ of the total revenue for the university sector as a whole (Danske Universiteter 2013, 4). Table 3.2 breaks down the types of funding in the period 2007-2013.

The data shows considerable growth across the main categories. Funding allocations for education increased by $30 \%$, and funding for both core research and external funding rose by $50 \%$ from 2007 to 2013 . That being said, when it comes to the sharing of competitive funding emanating from the ministry (official tasks), the figures have been rather stable 
Table 3.2 University funding from 2007 to 2013, Thousand Danish Kronerfixed prices ${ }^{\mathrm{a}}$

\begin{tabular}{lrrrrrrr}
\hline & 2007 & 2008 & 2009 & 2010 & 2011 & 2012 & 2013 \\
\hline $\begin{array}{l}\text { Core: } \\
\text { education }\end{array}$ & 6170.6 & 6269.3 & 6583.1 & 6944.1 & 7286.5 & 7621.1 & 8065.7 \\
$\begin{array}{l}\text { Core: } \\
\text { research }\end{array}$ & 6056.2 & 7374.7 & 8070.2 & 8330.8 & 8834.2 & 8868.9 & 9007.8 \\
$\begin{array}{l}\text { External } \\
\text { Ministry }\end{array}$ & 5385.5 & 5945.2 & 6282.7 & 6929.5 & 7188.7 & 7585.2 & 7950.6 \\
tasks & 536.9 & 508.8 & 541.1 & 505.9 & 517.3 & 489.2 & 488.7 \\
$\begin{array}{l}\text { Other } \\
\text { Total }\end{array}$ & 3738.4 & 2610.2 & 2759.6 & 2511.7 & 2339.4 & 2059.9 & 1917.8 \\
\hline
\end{tabular}

Source: Statistics from Universities Denmark

aFinal figures have been rounded for simplicity. The year 2006 is not included, as its figures are not comparable due to the merger of GRIs into the universities. "Other" includes example revenues for other purposes, as well as financial revenues

over time. Overall, university funding allocations across all categories increased by $25 \%$ during the seven-year period.

As is the case with the introduction of governance through contracts, several key policy developments, including the merger reform and the development of an increasingly results-based resource allocation system, are very much in line with the more general trends in public sector reforms. Other development initiatives include more specific higher education policy initiatives. This can be seen particularly in the case of the governance of reform that has been discussed since the 1970s, during which time a very democratic governance structure was introduced. However, it also applies to some of the adjustments of the resource allocation system; for example, the introduction of bonuses for students who complete their studies in due time. The key policy developments reflect an ongoing discussion and a dilemma between, on the one hand, leveraging university autonomy (the idea of turning universities into dynamic strategic actors), and on the other, fostering universities' political (societal) responsiveness and state control. In a nutshell, the merger reform reduced the number of institutions, thus turning governance through contracts into a more manageable process, whereas the governance reform introduced hierarchical structures into universities, turning (some) leaders into very responsive actors in the eyes of the government. 


\section{Recent Policy Initiatives}

In recent years, several policy initiatives have been developed that are aimed at boosting effectiveness and efficiency. On the teaching front, these initiatives have been geared towards increasing students' throughput, and on the research side, the bibliometric indicator may be interpreted as an initiative meant to increase research productivity as well as, to some extent, research quality. During the period between 2003 and 2014, the Danish government was concerned with both education and researchrelated issues; however, different governments attempted to balance the two sides of the system differently. For instance, the liberal government from 2001 to 2011 exhibited a very active research policy reform agenda, whereas the left-leaning government, which has been in power since 2011, has been more occupied with driving educational reforms. Towards the end of 2014, the political agenda shifted somewhat towards cutting back on educational programmes with high levels of graduate unemployment. Dimensioning initiatives have hit programmes within the humanities especially, but other areas have also been affected, for example, biology programmes. Below, we provide an overview of the key 2003-2014 policy initiatives aimed towards boosting performance in teaching, research, and doctoral education.

\section{Historical Overview}

Tables 3.3 and 3.4 outline a number of government-led initiatives in Denmark geared towards boosting the number of students in the higher education university system as well as initiatives for ensuring effectiveness and efficiency. The globalisation agreement increased the volume of the system in relation to research, especially with respect to $\mathrm{PhD}$ education. The increase in the number of youth applying to study at Danish universities (in 2011, marked by the political 25\% goal for 2020), combined with the taximeter resource allocation system, has boosted the volume of the system in relation to teaching. System growth and the potentially problematic incentives of allowing students to pass their exams (due to the taximeter system) have raised concerns about whether quality problems exist in the sector. This has led to policy initiatives aimed at ensuring quality by further developing the accreditation system and, more recently, including a quality indicator in the funding system. 
Table 3.3 Key policy initiatives within teaching

\begin{tabular}{|c|c|c|c|}
\hline Year & Measures taken & Rationale & $\begin{array}{l}\text { Reactions of higher } \\
\text { education } \\
\text { institutions }\end{array}$ \\
\hline 2007 & $\begin{array}{l}\text { Programme accreditation; all } \\
\text { new and established } \\
\text { programmes have to go through } \\
\text { accreditation }\end{array}$ & $\begin{array}{l}\text { Ensure quality and relevance of } \\
\text { programmes }\end{array}$ & $\begin{array}{l}\text { Negative; very } \\
\text { resource- and } \\
\text { time-consuming }\end{array}$ \\
\hline 2009 & $\begin{array}{l}\text { Bonus for students who } \\
\text { complete their studies in due } \\
\text { time }\end{array}$ & Improve throughput rates & $\begin{array}{l}\text { Negative; } \\
\text { universities did not } \\
\text { find that they were } \\
\text { able to influence } \\
\text { student behaviour }\end{array}$ \\
\hline 2011 & $\begin{array}{l}\text { New government agreed that } \\
25 \% \text { of all youngsters in } 2020 \\
\text { must obtain a master's degree }\end{array}$ & & \\
\hline 2013 & Fremdriftsreformen & $\begin{array}{l}\text { Ensure that students study full } \\
\text { time; improve throughput rates }\end{array}$ & Negative; see above \\
\hline & $\begin{array}{l}\text { Accreditation system changed to } \\
\text { institutional accreditation, } \\
\text { combined with administrative } \\
\text { approval of new programmes }\end{array}$ & $\begin{array}{l}\text { Ensure that universities have } \\
\text { optimal procedures for } \\
\text { ensuring the quality and } \\
\text { relevance of their programmes }\end{array}$ & $\begin{array}{l}\text { Rather positive; was } \\
\text { seen as an } \\
\text { improvement from } \\
\text { the former system }\end{array}$ \\
\hline 2014 & $\begin{array}{l}\text { Reducing the number of } \\
\text { students in programmes with } \\
\text { graduate unemployment } \\
\text { (dimensionering) }\end{array}$ & $\begin{array}{l}\text { Enhance graduates' } \\
\text { employability; cutting back on } \\
\text { certain programmes }\end{array}$ & $\begin{array}{l}\text { Overall positive, } \\
\text { but sceptical } \\
\text { towards the } \\
\text { technical design of } \\
\text { the system }\end{array}$ \\
\hline
\end{tabular}

Table 3.4 Key policy initiatives within research

\begin{tabular}{|c|c|c|c|}
\hline Timeline & Measures taken & Rationale & $\begin{array}{l}\text { Reactions of } \\
\text { higher education } \\
\text { institutions }\end{array}$ \\
\hline 2003-2005 & $\begin{array}{l}\text { Reform of the research } \\
\text { council system }\end{array}$ & $\begin{array}{l}\text { Separating strategic research } \\
\text { initiatives from responsive } \\
\text { mode funding and } \\
\text { establishing a foundation for } \\
\text { technology development }\end{array}$ & \\
\hline 2006 & $\begin{array}{l}\text { Globalisation } \\
\text { agreement }\end{array}$ & $\begin{array}{l}\text { Increased resources for } \\
\text { research }(2007-2012)\end{array}$ & Positive \\
\hline \multirow[t]{2}{*}{2010} & Bibliometric indicator & $\begin{array}{l}\text { Increased resources for } \mathrm{PhD} \\
\text { programmes }(2007-2012)\end{array}$ & Positive \\
\hline & $\begin{array}{l}\text { The Danish National } \\
\text { Research Foundation } \\
\text { evaluation increased } \\
\text { resources and, some } \\
\text { years later, cutbacks }\end{array}$ & & $\begin{array}{l}\text { Varied; some used } \\
\text { it actively, and } \\
\text { others mostly } \\
\text { ignored it }\end{array}$ \\
\hline 2014 & $\begin{array}{l}\text { Innovation Fund } \\
\text { Denmark }\end{array}$ & & \\
\hline
\end{tabular}




\section{Finland}

\section{Landscape}

The Finnish higher education system consists of two complementary sectors: universities and universities of applied sciences. Both sectors have their own distinct profiles and missions. As specified in Finnish legislation, the mission of universities is to conduct scientific research and provide undergraduate and postgraduate education based on this research. Universities must promote free research and scientific and artistic education, provide higher education based on research, and educate students so that they can serve their country and humanity. While carrying out this mission, universities must interact with the surrounding society and strengthen the influence of research findings and artistic activities on society (Universities Act 558/2009). In contrast, the mission of universities of applied sciences is to train professionals in response to labour market needs and to conduct applied research, development and innovation activities which supports instruction and promotes regional development in particular (Finnish Ministry of Education and Culture n.d.).

In 2013, there were altogether 14 universities operating under the auspices of Finland's Ministry of Education and Culture (see Table 3.5). All these universities offer bachelor's, master's, licentiate, and doctoral degrees. The standard degree obtained by students at Finnish universities is the master's degree. The bachelor's/master's distinction is more or less a formality introduced to align with the two-cycle Bologna system, as the bachelor's degree is not widely regarded as a degree with which one can enter the labour market.

\section{System Governance}

Finland's university sector is steered through legislation, performancebased funding, performance agreements, and quality assurance measures, as well as through national mid-term (five years) development plans before their abolishment in 2015. National legislation (acts and decrees) has a particularly strong influence on the structure of the Finnish university sector. Legislation determines the number of universities, the missions and tasks of the universities, the governance and administrative structures and bodies of the universities, the regulations related to studies and studying, the number of academic staff, and so on. 
Table 3.5 Universities in Finland, 2013 (all figures are FTE)

\begin{tabular}{|c|c|c|c|c|}
\hline University & Type & $\begin{array}{l}\text { Number of } \\
\text { students }\end{array}$ & $\begin{array}{l}\text { Number of } \\
\text { academic } \\
\text { staff }\end{array}$ & $\begin{array}{l}\text { Number of } \\
\text { non-academic } \\
\text { staff }\end{array}$ \\
\hline Aalto University & Multidisciplinary & 12,772 & 2845 & 1886 \\
\hline $\begin{array}{l}\text { Hanken School of } \\
\text { Economics }\end{array}$ & $\begin{array}{l}\text { Business } \\
\text { (Swedish-speaking) }\end{array}$ & 1696 & 130 & 109 \\
\hline $\begin{array}{l}\text { Lappeenranta } \\
\text { University of } \\
\text { Technology }\end{array}$ & Technical & 3270 & 588 & 351 \\
\hline $\begin{array}{l}\text { Tampere University } \\
\text { of Technology }\end{array}$ & Technical & 6147 & 1175 & 664 \\
\hline $\begin{array}{l}\text { University of } \\
\text { Eastern Finland }\end{array}$ & Multidisciplinary & 10,798 & 1497 & 979 \\
\hline $\begin{array}{l}\text { University of } \\
\text { Helsinki }\end{array}$ & Multidisciplinary & 23,505 & 4186 & 3493 \\
\hline $\begin{array}{l}\text { University of } \\
\text { Jyväskylä }\end{array}$ & Multidisciplinary & 9718 & 1512 & 917 \\
\hline $\begin{array}{l}\text { University of } \\
\text { Lapland }\end{array}$ & Multidisciplinary & 3193 & 304 & 273 \\
\hline University of Oulu & Multidisciplinary & 10,374 & 1645 & 989 \\
\hline $\begin{array}{l}\text { University of the } \\
\text { Arts Helsinki }\end{array}$ & Art & 1577 & 386 & 298 \\
\hline $\begin{array}{l}\text { University of } \\
\text { Tampere }\end{array}$ & Multidisciplinary & 10,045 & 1055 & 842 \\
\hline University of Turku & Multidisciplinary & 12,716 & 1758 & 1350 \\
\hline University of Vaasa & Multidisciplinary & 3622 & 285 & 196 \\
\hline $\begin{array}{l}\text { Åbo Akademi } \\
\text { University }\end{array}$ & $\begin{array}{l}\text { Multidisciplinary } \\
\text { (Swedish-speaking) }\end{array}$ & 4187 & 729 & 464 \\
\hline Total & & 113,620 & 18,095 & 12,811 \\
\hline
\end{tabular}

Source: Vipunen database

Finland's university admissions system has been highly decentralised in contrast to other European countries. Finnish universities are free to establish their own criteria for the admission of students. Entrance examinations, in the majority of cases, differ from one university to another. Unlike many other countries, all fields of study in Finnish universities apply numerous clauses to their admission policies. Universities are not allowed to initiate degree-based training in new disciplinary fields (e.g., engineering, medical science, or law) without the approval of the Ministry of Education and Culture. The purpose of this restriction is 
to ensure national coordination and the quality of the programmes within the scope of the higher education institutions' educational responsibilities, as well as the (public) resources available to them (Kivistö and Pekkola 2013). Otherwise universities have high levels of autonomy in developing their programme portfolios. This policy choice is based on the welfare state ideology in which forecasting labour (market) demands plays an important role due to the qualification requirements for many (public) professions, whereas university degrees have traditionally functioned as screening devices. Admission and degree targets for each field of education are agreed upon between them and contained in each higher education institution's performance agreement with the Ministry of Education and Culture. In 2015, the government decided to bring an end to all mid-term policy planning and concentrate more on strategic planning. Thus, the development plans are part of administrative history-for the time being (Kivistö and Pekkola 2013).

The national authorities that are primarily responsible for science and technology policy in Finland are the Ministry of Education and Culture and the Ministry of Employment and the Economy. The former is in charge of matters related to researcher training and science policy, as well as the Academy of Finland. The latter deals with matters related to industrial and technology policies, the National Technology Agency (TEKES) (renamed Business Finland as of 2018), and the Technical Research Centre of Finland (VTT). The bulk of public R\&D funding is channelled through these two ministries (cf. Ministry of Education 2005 ). Finnish national science, technology, and innovation policies are formulated by the Science and Technology Policy Council (1987-2008) and the Research and Innovation Council (since 2009), which were and are chaired by the Finnish Prime Minister. The role of these councils was and is to advise the government on the strategic development and coordination of Finnish science and technology policy as well as the national innovation system.

\section{Funding Structures}

From 2003 to 2013, state funding allocated through the funding model (core funding) was relatively stable and covered approximately $72-75 \%$ of total university funding, depending on the year (consult Fig. 3.1). The differences between the years, therefore, were no greater than $3 \%$. 
University core funding and external research funding (1000 €)

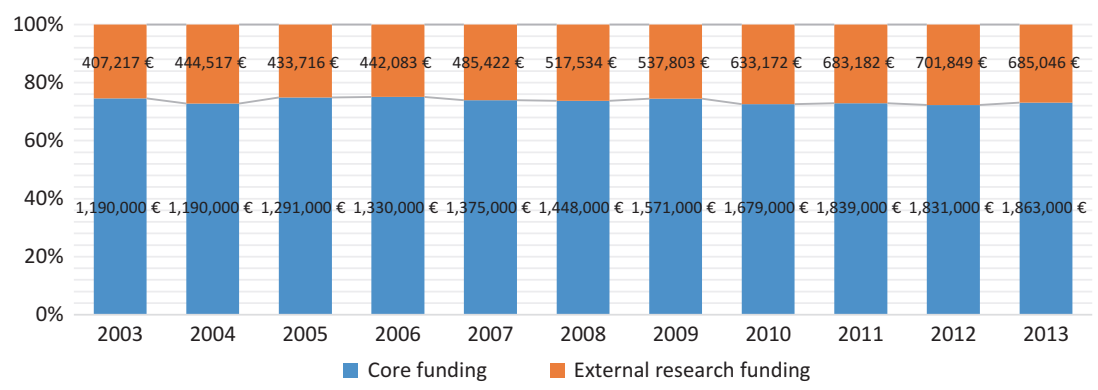

Fig. 3.1 University core funding and external research funding, 2003-2013. Source: Statistics Finland

Throughout the period between 2003 and 2013, the greatest share of external research funding was allocated by the Academy of Finland, in which the proportion of all research funding ranged between $31 \%$ and $39 \%$. Notably, during this decade, the share of the Academy of Finland's funding increased from $33 \%$ to $39 \%$. TEKES' share of total external research funding has been more stable; it ranged from $20 \%$ to $22 \%$, depending on the year. Similarly, the share of funding from the EU fluctuated between only $8 \%$ and $11 \%$, depending on the year. However, the relative share of domestic companies steadily decreased from 2008 (13\%) to $2013(8 \%)$, in both relative and absolute terms.

\section{Recent Policy Developments}

In 2010, the Finnish university system witnessed a profound reform that encompassed the implementation of a totally new legislation (Universities Act 558/2009) accompanied by a series of reform acts and policies known as the "structural development" of the entire higher education system. Consequently, universities became independent legal and economic entities, separate from state financial administration. Universities became either foundations under private law (Aalto University and the Tampere University of Technology) or corporations under public law (all the other universities). This meant that these universities assumed full financial liability for both their operations and their properties.

The change in legal status also meant a change in the status of the university staff, who were no longer employees of the state. Thus, civil service employment relationships were changed to contractual employment rela- 
tionships. This change permitted the universities to exercise more independent human resource policies, including staffing and the transfer of all related employer responsibilities (e.g., insurance and collective bargaining) to universities (Pekkola and Kivistö 2012). The New Universities Act pushed the universities towards a more professional model of management, with the board as the supreme decision-making body. One of the new responsibilities of the board was to appoint a rector. Previously, rectors had been elected by an election collegium. Moreover, in contrast to the previous situation in which the rector acted as the chairperson of the board, under the new act, the chairperson was to be elected among external board members. Universities were allowed to charge tuition fees for international master's programmes from non-EU/EEC students on a trial basis (2010-2014).

In 2008, as part of the reform of Finland's salary system, the salary system in the state's universities was also changed. The new salary system replaced the old system with salary categories and experience (age) bonuses. The new system was composed of two components: the task's requirement level (fixed) and individual performance level (0-46, 3\%). The reform of the salary system introduced a biannual evaluation of individual performance (including teaching, research, and other tasks) and an institutional two-partite mechanism to define the requirement levels in all departments and disciplines. In addition to the performance component in the salary, many universities introduced performance bonus systems.

From 2003 to 2013, the core funding for Finnish universities was allocated as a lump sum, primarily through a performance-based funding formula that covered approximately $70-90 \%$ of the total core state funding. The performance agreements between the Ministry of Education and Culture and each university set operational and qualitative goals and determined the resources required to reach these targets over a three- to fouryear period. However, the actual influence of these agreements has somewhat diminished due to the indicator-driven, performance-based funding system.

Thematic system-based evaluations form the basis of Finland's national evaluation and quality assurance system. The main actor pertaining to these evaluations has been the semi-autonomous Finnish Higher Education Evaluation Council (FINHEEC), which is responsible for conducting external quality assurance activities (though as of 2014, it is now the Finnish Education Evaluation Centre [FINEEC]). Finland does not have a higher education accreditation system per se; however, each institution 
is mandated by the Universities Act (in both the 1997 and the 2009 versions) to take part in external evaluation of their activities and quality assurance systems on a regular basis. In line with this requirement, Finnish universities were first audited by FINHEEC/FINEEC during the period between 2005 and 2012. The second round of audits, with a slightly revised auditing scheme, began in 2013. Contrary to the systems that evaluate all degree programmes in the same disciplinary field, each university established its own quality assurance system. Universities also became responsible for the quality and continuous development of their educational programmes and other operations. The evaluations are developmental in nature and are aimed towards helping institutions improve their operations (cf. Melin et al. 2015).

The Ministry of Education and Culture's policy of upgrading its university funding model every three years has been aligned with standard period of performance agreements between the Ministry and the universities from 2003 to 2013 . In the period between 2013 and 2015, the allocation (funding) model with regard to universities was completely restructured. The number of indicators incorporated into the new model was significantly lower compared to the model in the period 2010-2012. The rationale behind the restructuring was to further increase the clarity and transparency of the model and, at the same time, offer fewer but stronger incentives for universities to reach their expected outputs and outcomes. In addition to reducing the number of indicators, the 2013-2015 model introduced some new ones. The new teaching-related indicators included: the number of students who gained more than 55 study credits European Credit Transfer System (ECTS) within one academic year, the number of students who gained study credits in open university and non-degree programmes, the number of employed graduates, and the number of master's degrees awarded to foreign nationals. In the research component of the model, the new indicators included a revised way of calculating scientific publications, which were now linked to national classification scheme ("publication forum") levels based on impact assessment, "international teaching and research personnel," and "PhD degrees awarded to foreign nationals." As in the 2010-2012 model, the teaching and research components together comprised $75 \%$ of the core funding allocated through the model.

In terms of politics, the goal of increasing the share of private revenue (from sources other than tuition fees) has, in most cases, been considered favourably throughout the period 2003-2009. Finland's 
constitution guarantees tuition-free education for all students (apart from student union membership fees), based on the idea of higher education as a right rather than a privilege and a generous student support system supported by a progressive tax structure (Melin et al. 2015). Private contributions to higher education are limited to industry and foundation funding. Before passing the new Universities Act $(558 / 2009)$, changes in comprehensive government policies that encouraged the generation of private revenue have been minor or nonexistent. In terms of the development of new approaches to cost-sharing, the 2009 Universities Act encouraged universities to compete for international research funding and donations and to increase revenues from business ventures to diversify their funding bases. Due to its strong welfare state ideology, the practice of giving and donating in Finland is weak.

The most pressing policy concerns with respect to university education have been the policies' delayed entry into higher education, the long study durations, and problems associated with completion rates (cf. Melin et al. 2015). Between 2003 and 2013, several policy measures have been taken to tackle these challenges, namely, the introduction in 2005 of an ECTS system as part of the implementation of Bologna's policy in Finland and a transition period between 2005 and 2008 to the two-cycle degree system in all university degree programmes. In September 2008, all the degrees (with a few exceptions) granted by Finnish universities were Bologna-compatible, and the normative study durations for lower and higher level university degrees were set according to the Universities Act (1997, 2009).

\section{Historical Overview}

Tables 3.6 and 3.7 shed some light on the importance of Bologna's process in promoting efficiency and harmonisation within teaching (from 2005 ) as well as the mixed receptions such measures entail. On the research front, the policies pointed towards the effort to integrate policy streams across governmental portfolios. They also pointed towards a series of structural reforms aimed at enhancing the global competitiveness of higher education institutions as well as the social influence by promoting interdisciplinary collaborations across the board. 
Table 3.6 Key policy initiatives related to education

\begin{tabular}{|c|c|c|c|}
\hline Timeline & Measures taken & Rationale & $\begin{array}{l}\text { Reactions of higher education } \\
\text { institutions }\end{array}$ \\
\hline $\begin{array}{l}\text { 2005-the } \\
\text { present }\end{array}$ & ECTS & $\begin{array}{l}\text { European } \\
\text { harmonisation/ } \\
\text { efficiency }\end{array}$ & $\begin{array}{l}\text { Mixed; more administrative } \\
\text { work, but promotes the } \\
\text { accomplishment of European } \\
\text { higher education }\end{array}$ \\
\hline 2005-2008 & Two-cycle degrees & $\begin{array}{l}\text { European } \\
\text { harmonisation/ } \\
\text { efficiency }\end{array}$ & $\begin{array}{l}\text { Mixed; more administrative } \\
\text { work, but promotes the } \\
\text { accomplishment of European } \\
\text { higher education }\end{array}$ \\
\hline 2005 & $\begin{array}{l}\text { Restrictions for the } \\
\text { duration of study }\end{array}$ & Efficiency & $\begin{array}{l}\text { Mainly positive due to the } \\
\text { performance-based funding } \\
\text { model }\end{array}$ \\
\hline 2005 & $\begin{array}{l}\text { Changes in } \\
\text { study-related } \\
\text { benefits; better } \\
\text { conditions for loans }\end{array}$ & Efficiency & $\begin{array}{l}\text { Mainly positive due to the } \\
\text { performance-based funding } \\
\text { model }\end{array}$ \\
\hline
\end{tabular}

Table 3.7 Key policy initiatives related to research

\begin{tabular}{|c|c|c|c|}
\hline Timeline & Measures taken & Rationale & $\begin{array}{l}\text { Reactions of higher } \\
\text { education institutions }\end{array}$ \\
\hline $\begin{array}{l}2005- \\
\text { present }\end{array}$ & $\begin{array}{l}\text { Strengthened the } \\
\text { role of the Science } \\
\text { and Technology } \\
\text { Council }\end{array}$ & $\begin{array}{l}\text { To integrate science, } \\
\text { technology, higher } \\
\text { education, and } \\
\text { innovation policy }\end{array}$ & $\begin{array}{l}\text { Mixed to positive; more } \\
\text { emphasis placed on } \\
\text { competitive research } \\
\text { funding and additional } \\
\text { funding }\end{array}$ \\
\hline 2007-2013 & $\begin{array}{l}\text { Strategic Centres for } \\
\text { Science, Technology } \\
\text { and Innovation } \\
\text { (SHOKS) }\end{array}$ & $\begin{array}{l}\text { To create globally } \\
\text { competitive innovation } \\
\text { clusters }\end{array}$ & $\begin{array}{l}\text { Mixed; no major impact } \\
\text { on universities or their } \\
\text { funding }\end{array}$ \\
\hline post- 2013 & $\begin{array}{l}\text { Research institute } \\
\text { and funding reform }\end{array}$ & $\begin{array}{l}\text { To promote mergers for } \\
\text { larger and stronger } \\
\text { entities, multidisciplinary } \\
\text { research, and social } \\
\text { significance }\end{array}$ & $\begin{array}{l}\text { Mixed to positive; new } \\
\text { funding instruments and } \\
\text { more competition in the } \\
\text { research sector as a } \\
\text { whole }\end{array}$ \\
\hline
\end{tabular}




\section{Norway}

\section{Landscape}

The Norwegian higher education system consists of universities, specialised university institutions, and university colleges. All three of these institution types are regulated in the framework of the 2005 Act relating to universities and university colleges. The mission of higher education institutions is articulated around teaching, international high-quality research, and the dissemination of knowledge for public administration, cultural life, businesses, and industries (Act 2005, 1-1). Norwegian public higher education institutions are owned by the state and belong to the public sector and administration. However, they are granted academic and artistic freedom with respect to the academic content of their teaching and research activities, individual appointments, and organisational structures within the limits of the framework regulations (Act 2005, 1-5). Higher education and research in Norway are the responsibility of the Ministry of Education and Research. In 2013, a total of eight universities operated in Norway offering bachelor's (three years), master's (two years), and combined five-year programmes (e.g., teacher training), professional programmes, and doctoral degrees (three to four years). Our analyses also include the Norwegian School of Economics (NHH), which belongs to the category of specialised university institutions owned by the Norwegian state. Overall, close to 110,000 students enrolled in Norwegian universities in 2013, as shown in Table 3.8.

The Ministry of Education and Research determines the admission criteria for the education sector and carries the ultimate responsibility for state educational institutions, student welfare, and student financial support. There are no student fees in public universities. Universities and university colleges are also responsible for the student learning environment; they are usually connected to a student union that takes care of student welfare needs. The student unions are established by the Ministry of Education and Research but are not administered by a central government. The student welfare organisations are independent organisations, as stipulated in relevant legislation and regulations, and receive state funding, tuition fees, and access to office space and basic equipment (provided through educational institutions at no cost) in order to offer high-quality, reasonably priced services to students. The Norwegian Universities and Colleges Admission Service (NUCAS) is responsible for determining admission to most programmes at Norwegian universities; that said, some 
Table 3.8 Universities in Norway, 2013 (all figures are FTE)

\begin{tabular}{|c|c|c|c|c|}
\hline & Type & $\begin{array}{l}\text { Number of } \\
\text { enrolled } \\
\text { students }\end{array}$ & $\begin{array}{l}\text { Number of } \\
\text { academic } \\
\text { staff }\end{array}$ & $\begin{array}{l}\text { Total } \\
\text { number of } \\
\text { staff }\end{array}$ \\
\hline $\begin{array}{l}\text { Norwegian School of } \\
\text { Economics (NHH) }\end{array}$ & Specialised, business & 3370 & 260 & 398 \\
\hline $\begin{array}{l}\text { Norwegian University } \\
\text { of Science and } \\
\text { Technology (NTNU) }\end{array}$ & $\begin{array}{l}\text { Technical, } \\
\text { comprehensive } \\
\text { (research-intensive) }\end{array}$ & 22,935 & 2965 & 5029 \\
\hline University of Agder & $\begin{array}{l}\text { Comprehensive, } \\
\text { vocational }^{\mathrm{a}}\end{array}$ & 10,470 & 571 & 960 \\
\hline University of Bergen & $\begin{array}{l}\text { Comprehensive, } \\
\text { research-based }\end{array}$ & 14,895 & 2082 & 3463 \\
\hline University of Nordland & $\begin{array}{l}\text { Comprehensive, } \\
\text { vocational }\end{array}$ & 6015 & 319 & 558 \\
\hline University of Stavanger & $\begin{array}{l}\text { Comprehensive, } \\
\text { vocational }\end{array}$ & 9680 & 684 & 1144 \\
\hline University of Oslo & $\begin{array}{l}\text { Comprehensive, } \\
\text { research-based }\end{array}$ & 27,360 & 3394 & 6067 \\
\hline $\begin{array}{l}\text { University of } \\
\text { Troms } \varnothing \text {-The } \\
\text { Norwegian Arctic } \\
\text { University }\end{array}$ & $\begin{array}{l}\text { Comprehensive, } \\
\text { research-based }\end{array}$ & 10,400 & 1445 & 2613 \\
\hline $\begin{array}{l}\text { Norwegian University } \\
\text { of Life Sciences }\end{array}$ & $\begin{array}{l}\text { Specialised, natural } \\
\text { sciences }\end{array}$ & 4595 & 582 & 1045 \\
\hline Total & & 109,720 & 12,302 & 21,277 \\
\hline
\end{tabular}

Source: NSD, database for statistics in higher education

a“Comprehensive-vocational," refers to its origin as former university-college and stronger vocational profile (professional training)

institutions have their own admission systems. This applies to several private university colleges as well as university colleges that have entrance examinations or auditions.

The national government plays an important role in the Norwegian Research and Development (R\&D) system. At the political level, the responsibility for research is organised according to the "sector principle." Several ministries allocate sizable resources to research projects that are related to sectors within their respective domains. Research appropriations are widely distributed among several ministries. The Ministry of Education and Research is the largest source of governmental research funding and is responsible for the inter-ministerial coordination of national research poli- 
cies and the government's overall research funding. At the operational level, three agencies are largely accountable for implementing the government's research and innovation policies. The Research Council of Norway (RCN), acts as the only operational research policy agency in Norway. In addition to funding research, the RCN has a mandate to advise the government on research policy and to create communication and coordination arenas for actors in research, industry, and government. The Ministry of Research and Education and the Ministry of Trade, Industry, and Fisheries are the most important contributors to the RCN's budget, which was approximately NOK 7.67 billion in 2013. The other two, Innovation Norway and the Industrial Development Corporation of Norway (SIVA), are the primary public institutions which support innovation. Innovation Norway offers programmes and services to promote innovation at the regional and national levels, giving a particular focus to small- and medium-sized companies. SIVA is involved in the provision of science parks, incubators, and services (mainly to start-up firms).

The Norwegian higher education system was traditionally divided into a university sector and a college sector (Kyvik 2009), the latter established as part of an expansion of the educational system in the late 1960s and 1970s. Traditionally, university degree programmes were inspired by the continental university model, with a four-year first degree and a two-year second degree. Some professional degrees have differed from this structure (e.g., teaching programmes, medicine programmes, etc.). The system has changed dramatically in the last two decades, mainly as a result of the so-called Quality Reform (St. Meld. 27, 2000-2001). This reform, initiated by a conservative government in the late 1990s and further developed by a social-democratic government in a 2001 white paper and implemented within higher education institutions starting in 2003 (a regulation established by yet another conservative government), was an attempt to address several challenges in higher education. These issues involved the following needs:

- The need for improved efficiency in higher education and research (by the early 2000s Norwegian higher education experienced a high level of student dropout and delayed graduation).

- The need to enhance the quality of higher education (it was seen as problematic that students had little contact with teachers, oldfashioned teaching methods emphasised traditional lectures, and little emphasis was given to student learning). 
- The need to adjust Norwegian higher education to the ongoing Bologna Process and Norway's related obligations.

- The need to find a system of governing the higher education sector that would enable it to respond to the challenges listed above (Ministry of Education 2005).

As part of the Quality Reform, governance structures at the institutional level allowed universities full autonomy in relation to organisational and management issues below the board/rector level. In essence, this autonomy implied that individual institutions were to decide their own internal organisation and governance systems. However, at the institutional level, only two main models of institutional leadership could be chosen by the universities' boards. The standard model- seen as a continuation of existing governance arrangements - saw a rector elected by the staff of the individual institution. This model implied that the rector also became the board chairperson. However, if this model was chosen, the institution also had to establish dual leadership at the institutional level and had to appoint a director responsible for all administrative matters (Stensaker 2014). The alternative governance model was one where the rector was appointed by the board for a limited time. An external member of the board then had to become the chairperson. If the rector was appointed, he/she had full academic and administrative responsibility, and the law did not demand the appointment of a director. A two-thirds majority among board members was required for an institution to opt for this alternative model. Following the standard rule, a board consisted of 11 members.

Following the Quality Reform, a new funding scheme for higher education was also introduced in 2004. The development of this scheme can be said to represent a continuation of earlier changes in funding, emphasising an output and performance system orientation. The most important change in the system was that a greater part of the budget became dependent on results, and several new "performance indicators" were therefore introduced. In 2017, the funding system was adjusted to include a performance indicator that incentivises universities to become more entrepreneurial in the acquisition of external funds, further incentives to improve students' throughput rates, and adjustments to the publishing indicator to ensure that all subject areas counted equally and that both national and international research cooperation are stimulated. 
As part of the budgeting process, the Ministry requires an annual report from every higher education institution on its results, achievements, and future plans. This report is also used as the foundation for consultative annual meetings between representatives of the Ministry and of the individual institution. The reports and meetings are important for monitoring and for setting targets and objectives for the coming years. This form of dialogue-based approach between the Ministry and public higher education institutions has a long tradition in Norwegian higher education (Bleiklie et al. 2000), and in recent years, it has been formalised as the standard procedure. As part of the Quality Reform, a new scheme for student financial support, aimed at providing more incentives for students to graduate on time, was also introduced.

In the 2003 quality reform, accreditation of all institutions within the Norwegian higher education system was introduced alongside systematic evaluations of institutional quality assurance systems. This accreditation system can be said to represent a new way to categorise the institutions within the Norwegian higher education landscape, where institutional autonomy is conditioned by an institution's status within the accreditation system. For example, if an institution is accredited as a university, it is given full rights regarding the establishment and cessation of degree programmes at all levels.

The establishment of a national database for higher education (called the DBH-NSB) has also been an important step towards improving both the system's accountability and information about its performance. The DBH-NSB was established prior to the Quality Reform but has received much more attention in the last decade. This database, which is accessible to everyone and is frequently used by newspapers and other media, contains information on staff, students, and student mobility, as well as financial data; it is mainly used by the Ministry of Education and Research for planning, monitoring, and budgetary purposes.

As a result of participating in the Bologna Process, a new degree structure was also launched through the 2003 Quality Reform. Restructured bachelor's, master's, and doctorate degrees (according to the three-year bachelor, two-year master, and three-year doctorate degree model) and a new grading system based on the ECTS were introduced. The new degree structure could be considered a rather dramatic change to the system, as it involved the establishment of a series of shorter modules with examinations for each within a given study programme (Michelsen and Aamodt 2006). In addition to the structural 
change at the programme level, new forms of student guidance were also introduced, with evaluation and assessment systems aimed at improving student feedback, reducing dropout and study interruption, and encouraging students to complete their programmes on time.

\section{Funding Structures}

Approximately $80 \%$ of governmental funding for R\&D in higher education institutions is channelled directly from the Ministry of Education and Research, mainly as institutional funding. Most of these funds are given through block funding as a lump sum. The rest is distributed based on reported student performance, research performance, and strategic research considerations. Since 2003, resulting from the Quality Reform, a new institutional funding structure has been in place. It consists of three core components:

- Basic funds, which are block funds without detailed use specifications. This component originally accounted for about $60 \%$ of institutional funding (on average for all universities) but has decreased somewhat.

- A teaching component, by which funds are distributed on the basis of reported student performance; this component initially amounted to approximately $25 \%$ of institutional funding and has increased somewhat.

- A research component, which amounts to approximately $15 \%$ of institutional funding. This component is subdivided into two parts, a performance-based part and a strategic part, within which earmarked funds are allocated to specific institutions for hiring $\mathrm{PhD}$ students and for acquiring/maintenance of scientific equipment.

From 2008 to 2013, state subsidies allocated to universities increased by $79 \%$, while total revenues in the decade $2003-2013$ more than doubled after a $129 \%$ increase (Table 3.9). The ratio of core funding to competitive funding has remained largely constant in recent years. However, the changes in the structure of core funds indicate a greater recent emphasis on performance- and strategy-based core research funding. Competitive funding is mainly channelled through the RCN. Central RCN funding schemes involve a competitive national arena for researcher-initiated basic research projects (FRIPRO) and so-called large-scale programmes covering strategic areas of national research policies. The FRIPRO scheme is 
Table 3.9 Universities' core funding, selected years for the period 2003-2013 (in billion Norwegian Kroner or NOK, rounded figures)

\begin{tabular}{llllllll}
\hline & 2003 & 2005 & 2008 & 2010 & 2011 & 2012 & 2013 \\
\hline State subsidies & NA & NA & 108.4 & 167.8 & 182.8 & 185.9 & 193.8 \\
Revenue & 110.9 & 122.5 & 103.7 & 220.3 & 239.7 & 242.7 & 253.8 \\
\hline
\end{tabular}

Source: DBH-NSB

Table 3.10 University research funding per source, 2003-2013 (in billion NOK, rounded figures)

\begin{tabular}{lclcllll}
\hline & $\begin{array}{c}\text { Lump sum } \\
\text { (state grant) }\end{array}$ & $\begin{array}{l}\text { Total } \\
\text { external }\end{array}$ & Industry & $\begin{array}{l}\text { Public } \\
\text { sector }\end{array}$ & $R C N$ & $\begin{array}{c}\text { Overseas } \\
\text { total }\end{array}$ & EU \\
\hline 2003 & 48.8 & 26.1 & 3.7 & 17.2 & 13.8 & 2.2 & NA \\
2005 & 58.3 & 32.3 & 4.3 & 21.8 & 16.7 & 2.8 & NA \\
2007 & 75.8 & 41.5 & 4.7 & 29.6 & 19.8 & 2.9 & 1.5 \\
2009 & 89.6 & 44.9 & 5.1 & 31.9 & 23.7 & 3.3 & 1.8 \\
2011 & 94.4 & 48.2 & 5.7 & 34.8 & 25.2 & 2.7 & 2.4 \\
2013 & 108.2 & 51.2 & 6.6 & 35.2 & 20.2 & 3.3 & 2.6 \\
\hline
\end{tabular}

Source: DBH-NSD and NIFU database

funded by appropriations from the Ministry of Research and Education and corresponds to about $15 \%$ of the RCN's annual budget. Over the years, state funding allocated through core funding has regularly increased by an average of $5 \%$ per year, as shown in Table 3.10. The greatest share of external research funding has been allocated by the RCN at around $4-5 \%$. EU framework programmes have accounted for, on average, around $1 \%$.

\section{Recent Policy Developments}

In 2014, the then new centre-right government put forward a reform agenda for the entire higher education sector, aiming to build strong academic environments capable of carrying out research and addressing important social challenges. This occurred despite the presence of strong research environments in select areas (most notably, within the life sciences and biomedical research) and improvements in international research aspects (Gornitzka and Langfeldt 2008). In comparison with other Nordic countries, Norwegian research lags somewhat. Among other concerns, the government worries that universities do not assert themselves com- 
petitively for EU funding, despite Norway's generous contributions to the EU's financial mechanism, most notably within the programmes run by the European Research Council (ERC).

A series of evaluations conducted in recent years point to academic environments without critical mass, lacking sufficient stability, and facing efficiency issues. As a result, a new wave of mergers and restructuring has been taking place as part of a reorganisation process, initiated in 2014, that focuses on a structural reform of the entire sector (Kyvik and Stensaker 2013). The current policy moves away from the traditional binary of universities and non-university institutions and instead focuses on smaller, but more robust and competitive, universities with distinctive teaching and research profiles. That said, there are serious concerns with respect to the growing homogenisation (in the convergence of structures, strategies, and programmes) that has resulted from these mergers (Pinheiro et al. 2016) and the resulting erosion of diversity that has historically characterised the domestic higher education system (Pinheiro and Stensaker 2018; Skodvin and Lid 2018).

Quality development and specialisation have become cornerstones of recent policy initiatives, resulting in a 2016-2017 white paper on higher education quality (St. Meld. 16 2016-2017). In addition to the use of merging, quality and specialisation is to be achieved in the following ways:

- Channelling a considerable amount of result-based public funding via student graduation or throughput rates;

- Developing fit-for-purpose performance indicators for quality measures;

- Enacting new incentives, for institutions and academics alike, to prioritise high-quality education, as has been the case regarding research excellence (Skodvin and Lid 2018, 408).

Other key priorities of the ongoing reform process include an update of the long-term strategy for higher education and research (for the period 2015-2024), a revamping of teaching education (as the foundation for a "knowledge society"), and a revision of the working conditions of academic staff, including recruitment, employment, and career structure. A process is currently underway to improve the attractiveness of the academic profession, with a focus on the recruitment and retention of talented individuals. This includes a future revamping of the tenure-based career track that has traditionally been composed of only two stages: 
associate and full professorships. A new third category of "senior professors," focussing on top achievers, is being considered.

\section{Historical Overview}

Table 3.11 below demonstrate the major changes from 2002 to 2013 relating to the implementation of the Quality Reform and the policy efforts put towards European compatibility, efficiency, and accountability (within the teaching realm). Measures to promote scientific excellence and the global competitiveness of the domestic research environment within universities are also considered (Table 3.12).

Table 3.11 Key policy initiatives related to education

\begin{tabular}{|c|c|c|c|}
\hline & Measures taken & Rationale & $\begin{array}{l}\text { Reactions by higher education } \\
\text { institutions }\end{array}$ \\
\hline $2002 / 2003$ & $\begin{array}{l}\text { New degree } \\
\text { structure }\end{array}$ & $\begin{array}{l}\text { Efficiency European } \\
\text { harmonisation } \\
\text { (Bologna Process) }\end{array}$ & $\begin{array}{l}\text { Implemented without major } \\
\text { resistance }\end{array}$ \\
\hline $2002 / 2003$ & $\begin{array}{l}\text { New funding } \\
\text { system }\end{array}$ & $\begin{array}{l}\text { Performance- } \\
\text { orientation; student } \\
\text { graduation and credit } \\
\text { production }\end{array}$ & $\begin{array}{l}\text { Implemented without major } \\
\text { resistance despite critics of the } \\
\text { "market" (including student } \\
\text { groups) }\end{array}$ \\
\hline $2002 / 2003$ & $\begin{array}{l}\text { Quality assurance } \\
\text { agency } \\
\text { ("NOKUT") }\end{array}$ & $\begin{array}{l}\text { Provide oversight and } \\
\text { international } \\
\text { comparison }\end{array}$ & $\begin{array}{l}\text { Relatively uncontroversial, } \\
\text { given that universities were } \\
\text { given more autonomy }\end{array}$ \\
\hline $2002 / 2003$ & $\begin{array}{l}\text { Strengthening } \\
\text { managerial } \\
\text { autonomy }\end{array}$ & $\begin{array}{l}\text { Improve accountability } \\
\text { and efficiency }\end{array}$ & $\begin{array}{l}\text { Positively, despite some } \\
\text { academic criticism of } \\
\text { managerialism }\end{array}$ \\
\hline
\end{tabular}

Table 3.12 Key policy initiatives related to research

\begin{tabular}{|c|c|c|c|}
\hline & Specific measures taken & Rationale & $\begin{array}{l}\text { Reactions by higher education } \\
\text { institutions }\end{array}$ \\
\hline 2003 & $\begin{array}{l}\text { Establishment of the } \\
\text { Centres of Excellence } \\
\text { scheme }\end{array}$ & $\begin{array}{l}\text { Excellence and global } \\
\text { competitiveness }\end{array}$ & Positively \\
\hline 2003 & $\begin{array}{l}\text { Bibliometric system } \\
\text { (based on two levels) }\end{array}$ & $\begin{array}{l}\text { Incentive to research } \\
\text { productivity }\end{array}$ & $\begin{array}{l}\text { Positively for the most part, } \\
\text { despite some criticisms on the } \\
\text { process for determining the } \\
\text { publication levels (levels } 1 \text { and } \\
2 / \text { highest) in certain fields. }\end{array}$ \\
\hline
\end{tabular}




\section{Sweden}

\section{Landscape}

All higher education is offered by public institutions or independent education providers granted degree-awarding powers by the government. Third-cycle courses and programmes are offered by universities or university colleges that have been granted the entitlement to award third-cycle qualifications. There are 14 public universities and 17 public university colleges in Sweden. In addition, there are three independent institutions that are entitled to award either all or some third-cycle qualifications: Chalmers University of Technology, the Stockholm School of Economics, and Jönköping University. In addition, there are nine independent education providers entitled to award first-cycle and, in some cases, second-cycle qualifications; four independent course providers are also entitled to award qualifications in psychotherapy (Table 3.13).

To be able to award a specific qualification, each institution offering a programme - whether it is accountable to the state or is independent-is required to have degree-awarding powers (i.e., special permission to award particular qualifications). Universities are entitled to award first-, second-, and third-cycle general qualifications. Public university colleges have a general entitlement to award diplomas, bachelor's degrees, and 60-credit master's degrees. Those granted the ability to award third-cycle qualifications within one or more specified fields, according to new regulations from 2010, are also entitled to award 120-credit master's degrees in specified fields. The Higher Education Act stipulates, however, that each higher education institution has the right to apply to the Swedish Higher Education Authority for the entitlement to award 120-credit master's degrees in one or more fields of study. In other cases, the government or SHEA determine institutional entitlement to award general qualifications. In the case of first- and second-cycle professional qualifications and all cycle qualifications in the fine, applied, and performing arts, both universities and university colleges must apply to SHEA for degree-awarding powers. In addition, university colleges must apply to SHEA for the entitlement to award third-cycle qualifications. Independent education providers must apply to the government for degree-awarding powers. This is also the case for the Swedish University of Agricultural Sciences and the National Defence College. 
Table 3.13 The Swedish university landscape, 2013 (all figures as FTE)

\begin{tabular}{|c|c|c|c|c|}
\hline & University type & $\begin{array}{l}\text { Total number } \\
\text { of students }\end{array}$ & $\begin{array}{l}\text { Total number of } \\
\text { academic staff }\end{array}$ & $\begin{array}{l}\text { Total } \\
\text { number of } \\
\text { staff }\end{array}$ \\
\hline Uppsala University & Comprehensive & 24,621 & 3017 & 6237 \\
\hline Lund University & Comprehensive & 27,702 & 2997 & 7166 \\
\hline $\begin{array}{l}\text { University of } \\
\text { Gothenburg }\end{array}$ & Comprehensive & 24,781 & 2491 & 5192 \\
\hline Stockholm University & Comprehensive & 29,555 & 2227 & 4578 \\
\hline Umeå University & Comprehensive & 16,015 & 1935 & 3897 \\
\hline Linköping University & Comprehensive & 17,716 & 1633 & 3432 \\
\hline Karolinska Institute & $\begin{array}{l}\text { Specialised, } \\
\text { medical }\end{array}$ & 6027 & 2097 & 4791 \\
\hline $\begin{array}{l}\text { KTH Royal Institute } \\
\text { of Technology }\end{array}$ & $\begin{array}{l}\text { Specialised, } \\
\text { technical }\end{array}$ & 12,000 & 1533 & 3875 \\
\hline $\begin{array}{l}\text { Luleå University of } \\
\text { Technology }\end{array}$ & $\begin{array}{l}\text { Specialised, } \\
\text { technical }\end{array}$ & 7823 & 632 & 1510 \\
\hline $\begin{array}{l}\text { Swedish University of } \\
\text { Agricultural Sciences }\end{array}$ & $\begin{array}{l}\text { Specialised, } \\
\text { agricultural }\end{array}$ & 3835 & 1381 & 3015 \\
\hline Karlstad University & Comprehensive & 7994 & 593 & 1047 \\
\hline Linnaeus University & Comprehensive & 13,817 & 952 & 1704 \\
\hline $\begin{array}{l}\text { Mid Sweden } \\
\text { University }\end{array}$ & Comprehensive & 6840 & 467 & 864 \\
\hline Örebro University & Comprehensive & 8615 & 542 & 1048 \\
\hline $\begin{array}{l}\text { Chalmers University } \\
\text { of Technology }\end{array}$ & $\begin{array}{l}\text { Specialised, } \\
\text { technical }\end{array}$ & 8926 & 1173 & 2863 \\
\hline $\begin{array}{l}\text { Stockholm School of } \\
\text { Economics }\end{array}$ & $\begin{array}{l}\text { Specialised, } \\
\text { business }\end{array}$ & 1804 & 105 & 224 \\
\hline Total & & 218,071 & 23,775 & 51,443 \\
\hline
\end{tabular}

Source: UKÄ (Annual report 2014)

\section{System Governance}

In Sweden, the overall responsibility for higher education and research rests with the Riksdag (the Swedish parliament) and the government, which decide on the regulations that apply to higher education. The Riksdag decides which public higher education institutions may be established. The government determines whether an institution has university status and outlines the objectives, guidelines, and the allocation of resources for higher education and research. The Ministry of Education and Research handles issues relating to schooling, higher education institutions, research, adult education, public education, and student finance. Public 
higher education institutions are accountable to the Ministry of Education and Research. One exception is Sveriges Lantbruksuniversitet (the Swedish University of Agricultural Sciences), which is accountable to the Ministry for Rural Affairs.

In Sweden, public higher education institutions are agencies in their own right that report directly to the government. The operations of higher education institutions are regulated by laws and statutes. Higher education institutions are also subject to administrative and labour-market legislation and the provisions of the Instrument of Government. Operations are also governed by the parameters and funding determined by the Riksdag and the government. The mission of the higher education institutions is to offer education based on an academic or artistic foundation and proven experience. They must also undertake developmental work, including research and artistic development. In addition, higher education institutions must co-operate with their surrounding communities, provide information about their operations, and act to ensure that benefits are derived from the findings of their research.

Higher education in Sweden is governed by the Higher Education Act and the Higher Education Ordinance. The Higher Education Act was enacted by the Riksdag and contains regulation on the operations of higher education institutions, which are often supplemented by the provisions laid down in the Higher Education Ordinance. The Higher Education Act's regulations focus on the courses and programmes offered by higher education institutions. For instance, the Act characterises courses and programmes at different levels and stipulates the freedom of research. It also provides a framework for the organisation and governance of higher education institutions and states that every institution must have a board of governors and a vice-chancellor. Additionally, the Act regulates the duties of teachers and contains provisions on student influence. It requires that higher education institutions foster equal opportunity and broaden their recruitment.

The Higher Education Ordinance was enacted by the government and is linked to the provisions of the Higher Education Act; for instance, the Ordinance states that students must be able to influence their courses and programmes. It also contains regulations on entrance qualifications, the selection of courses and programmes, and the appointment of teachers and doctoral students. In addition, it regulates course and programme syllabi, grades, and qualifications. 
Annex 2 to the Higher Education Ordinance and the annexes to the Ordinance on the Swedish University of Agricultural Sciences and the Ordinance on the Swedish National Defence College are qualifications ordinances that contain the descriptors for all institutions. Within these parameters, higher education institutions are relatively free to decide their own organisation, allocation of resources, and course offerings. The system is based on the principle of management by objectives. The government lays down the directives for operations of higher education institutions in annual public service agreements. The Swedish Higher Education Authority, a government agency responsible for quality assurance, legal supervision and for monitoring efficiency, supervises these institutions to ensure their compliance with the relevant statutes and regulations and also reviews the quality of higher education and the efficiency and effectiveness of resources and public funding within it.

\section{Funding Structures}

The Riksdag determines the funding for higher education institutions. Resources are allocated to institutions for first- and second-cycle courses and programmes according to the number of students enrolled in each cycle, expressed in terms of full-time equivalents (FTEs) and the number of credits attained (which are annual performance equivalents). Every year, the government determines an institutional funding cap-the maximum amount that can be given to each institution. In June 2010, the Riksdag decided that resources for first- and second-cycle programmes are also to be allocated according to the results of the Higher Education Authority's quality evaluations. This meant that institutions with the highest ratings are incentivised with additional funding (a measure called "quality funding"). Quality-based resource allocation applies to public higher education institutions as well as the Chalmers University of Technology and the Jönköping University Foundation; this type of allocation was effective as of 2013. Direct funding for research and thirdcycle courses and programmes is based mainly on past allocations, but since 2009 , about $10 \%$ of funding and new resources have been allocated on the basis of two quality indicators: reported publications and citations and the amount of research funding from external sources. The Swedish University of Agricultural Sciences has a special budgeting and reporting system by which funding for research, courses, and programmes is allocated for three-year periods alongside educational targets for the same periods (Table 3.14). 
Table 3.14 University education and research funding per source, 2003-2013 (in million SEK)

\begin{tabular}{lllllllllllll}
\hline & 2003 & 2004 & 2005 & 2006 & 2007 & 2008 & 2009 & 2010 & 2011 & 2012 & 2013 \\
\hline $\begin{array}{l}\text { Total } \\
\text { research }\end{array}$ & 3175 & 3106 & 3282 & 3240 & 3448 & 3717 & 3975 & 4130 & 4306 & 4672 & 4874 \\
$\begin{array}{l}\text { income } \\
\text { Research } \\
\text { income } \\
\text { (external) }\end{array}$ & 1781 & 1662 & 1799 & 1717 & 1862 & 2029 & 2274 & 2094 & 2239 & 2481 & 2666 \\
$\begin{array}{l}\text { Research } \\
\text { income } \\
\text { (other) }\end{array}$ & 1394 & 1444 & 1483 & 1523 & 1586 & 1688 & 1701 & 2036 & 2067 & 2191 & 2208 \\
$\begin{array}{l}\text { Income for } \\
\text { first and } \\
\text { second cycle } \\
\text { education }\end{array}$ & 1698 & 1705 & 1713 & 1919 & 1875 & 1962 & 2216 & 2271 & 2247 & 2281 & 2357 \\
$\begin{array}{l}\text { Direct state } \\
\text { funding as a } \\
\text { share of }\end{array}$ & 65.2 & 64.6 & 65.7 & 62.8 & 64.8 & 65.5 & 64.2 & 64.5 & 65.7 & 67.2 & 67.4 \\
income (\%) \\
$\begin{array}{l}\text { Share of } \\
\text { external } \\
\text { research } \\
\text { funding (\%) }\end{array}$
\end{tabular}

Source: Högskoleverket and UKÄ (annual reports from 2004, 2006, 2008, 2010, 2012, and 2014)

\section{Recent Policy Developments}

Turning now to the evolution of the system, an important reform in Swedish higher education was launched in the early 1990s when the current funding and governance system was introduced (Geschwind 2017). In June 2005, the Swedish government presented proposals to reform its higher education system according to the Bologna Process (Swedish Govt. Bill 2004/2005, 162). The bill was adopted by the parliament in February 2006; changes to the Higher Education Act and the Higher Education Ordinance commenced on 1 July 2007. In 2009, the bill for greater autonomy in higher education institutions (Swedish Govt. Bill 2009/2010, 149) created additional opportunities to transform domestic providers. Faculty boards were no longer mandatory or regulated by the Higher Education Ordinance, as was the case before. In brief, the bill stated the following: 
- Higher education institutions shall have a board and a president, but are otherwise free to develop their own organisation.

- Decisions requiring a particular, qualified assessment must be made by people with scientific or artistic qualifications.

- Students have the right to representation when decisions are taken or preparations are made that significantly affect their education or situations.

- Staff in the categories of "Professor" and "Senior Lecturer" will continuously be regulated by the Higher Education Ordinance. Otherwise, higher education institutions can choose their own career structures and staff categories. They can also recruit staff to professorships without the need for the traditional open competition.

- Education will be less governmentally regulated, and some stateregulated examination goals shall be abolished.

The bill “A Reformed Constitution" (Swedish Govt. Bill 2009/2010, 80 ) also included two amendments to increase the freedom of higher education institutions. The amendments came into effect on 1 January 2011 and introduced new provisions to protect the freedom of research. Furthermore, the stipulation that heads of government agencies and members of government agency boards must be Swedish citizens was removed from the instrument of government but can instead be included in an act of primary legislation. The bill also emphasised the continued importance of collegial bodies at colleges and universities and increased their freedom in organising their internal affairs. In particular, it abolished the regulation requiring there be a faculty board at every institution, resulting in a debate on whether collegiality is at risk of elimination at Swedish universities.

According to a 2000-2001 bill (Swedish Govt. Bill 2000/2001), strong research environments were to be established through funding from the then new Swedish Research Council (Vetenskapsrådet). Its belief is that "...to sustain the position as a leading research nation, a mobilisation is needed in Swedish research" (Swedish Govt. Bill 2000/2001, 12). From its foundation, the Research Council has funded "basic research of highest quality," initially by primarily funding individuals or small teams of researchers. As a response to competition from the initiatives of private foundations and pressure from the Swedish government, which pushed for such schemes, Centre of Excellence schemes were eventually introduced despite some hesitation from the Council. 
In the following research bill (Swedish Govt. Bill 2004/2005), a new type of large-scale funding programme was launched, inspired by international developments. Consequently, a number of schemes were established from 2005 onwards, including one with scientific excellence as the overall objective (the Linnaeus Environments), another focussed on economic rationales and innovation (the VINN Excellence Centres), and several other schemes with multiple objectives. These other schemes included the FAS Centers (aiming at scientific excellence, social challenges, and strategic objectives), the Berzelii Centres (aiming at scientific excellence, economic rationales, and innovation), and the Strategic Research Centres (aiming at social challenges, strategic objectives, economic rationales, and innovation). The latter scheme was funded by a private foundation. The total number of centres funded by the schemes mentioned above is nearly 100, of which 20 were hosted by the dominating institution, Lund University.

The implementation of these excellence centres was delegated to the funding bodies (i.e., the research councils and the innovation agency VINNOVA). In the following 2008 bill (Swedish Govt. Bill 2008/2009), the further concentration and prioritisation of resources was at the policy forefront. In line with previous bills, the government criticised earlier allocation models based on historical criteria (i.e., head counts) rather than excellence, per se. Instead of allocating direct state funding as block grants, more high-profile institutions and prioritisation were now desired. The policy solution to this was termed "Strategic Research Areas" (SROs) and involved long-term funding for designated areas based on an institution's publications, citations, and ability to attract external funding (Benner 2008).

In the 2012-2013 research and innovation bill (Swedish Govt. Bill $2012 / 2013$ ), the quality target was further developed. Compared to earlier bills, a stronger emphasis was put on the role of direct state funding as a precondition for breakthrough research: "...it is the government's opinion that it is natural to let a bigger share of the funding than before be allocated according the quality measures introduced in the previous research and innovation bill" (Swedish Govt. Bill 2012/2013, 17). Notably, the earlier focus on "big environments" had shifted to one on "excellent individuals," including both researchers early in their careers and internationally recognised scholars. Additionally, a new system for resource allocation based on peer review (inspired by the British 
Research Excellence Framework, among other models) was investigated and a proposal was submitted to the government. Currently, a government inquiry is investigating the governance and funding structures of the Swedish higher education system (Strut 2019).

Regarding education quality and accreditation, Sweden introduced a national quality assurance system in the early 1990s. Initially, its focus was on accreditation and institutional audits. From 2001 to 2006, a comprehensive evaluation of all programmes and subjects culminating in a degree was undertaken by peer review teams. After the round of reviews completed in 2014, excellence could be rewarded financially. The current system has changed its focus again, now evaluating quality assurance systems at the institutional level and, by doing so, returning to the concept of higher education institutions being responsible for their own quality assurance. Furthermore, the Swedish Higher Education Authority (UKÄ) has been entrusted with the task of evaluating research (again at the quality system level).

Additionally, according to the Higher Education Ordinance, higher education institutions since 2010 have had the right to summon and appoint a staff member as a full professor if he/she is of significant importance to the academic environment. This procedure (known as Kallelseförfarandet) should be used restrictively and per the decisions of the vice-chancellor. Since its launch, 40 people (as of the autumn of 2013) have been summoned, of which 30 were men and 10 were women.

\section{Historical Development}

The tables below demonstrate that policy efforts focussing on revamping the governance and funding systems and on teaching quality span more than two decades. In the last decade, policy focus has shifted to deregulation and efficiency imperatives-measures that received little resistance at the system level. When it comes to research, as seen in the other three countries (policy convergence), the policy focus has been on incentive systems and structural changes aimed at promoting excellence and global competitiveness (Tables 3.15 and 3.16).

Acknowledgements The data presented in the current volume and individual chapters emanate from a comparative study funded by the Norwegian Research Council under its FINNUT flagship program, a long-term program for research and innovation in the educational sector program. The project number was 237782, and the project was titled 'Does it matter? Assessing the performance effects of changes in leadership and management structures in Nordic Higher Education'. 
Table 3.15 Key policy initiatives related to education

\begin{tabular}{|c|c|c|c|}
\hline Timeline & Measures taken & Rationale & $\begin{array}{l}\text { Reactions by } \\
\text { Higher Education } \\
\text { Institutions (HEIs) }\end{array}$ \\
\hline 1993 & $\begin{array}{l}\text { New governance and } \\
\text { funding systems }\end{array}$ & $\begin{array}{l}\text { Performance-orientation; student } \\
\text { graduation and credit production } \\
\text { Deregulation of academic } \\
\text { positions and educational } \\
\text { programmes }\end{array}$ & $\begin{array}{l}\text { Implemented } \\
\text { without major } \\
\text { resistance }\end{array}$ \\
\hline 1995 & $\begin{array}{l}\text { New quality assurance } \\
\text { agency } \\
\text { (Högskoleverket) }\end{array}$ & $\begin{array}{l}\text { To undertake accreditation, } \\
\text { evaluations, and institutional } \\
\text { audits }\end{array}$ & $\begin{array}{l}\text { Implemented } \\
\text { without major } \\
\text { resistance }\end{array}$ \\
\hline 2001 & $\begin{array}{l}\text { Strengthened } \\
\text { institutional } \\
\text { autonomy }\end{array}$ & $\begin{array}{l}\text { Deregulation of organisational } \\
\text { units and academic positions }\end{array}$ & $\begin{array}{l}\text { Implemented } \\
\text { without major } \\
\text { resistance }\end{array}$ \\
\hline 2005 & New degree structure & $\begin{array}{l}\text { Efficiency European } \\
\text { harmonisation (Bologna) }\end{array}$ & $\begin{array}{l}\text { Implemented } \\
\text { without major } \\
\text { resistance }\end{array}$ \\
\hline
\end{tabular}

Table 3.16 Key policy initiatives related to research

\begin{tabular}{llll}
\hline Timeline & Measures taken & Rationale & $\begin{array}{l}\text { Reactions by Higher } \\
\text { Education Institutions } \\
\text { (HEIs) }\end{array}$ \\
\hline $2004 / 2005$ & $\begin{array}{l}\text { Establishment of Centre } \\
\text { of Excellence schemes } \\
\text { Performance-based } \\
\text { funding based on metrics }\end{array}$ & $\begin{array}{l}\text { Excellence and global } \\
\text { competitiveness } \\
\text { Incentive to research } \\
\text { productivity }\end{array}$ & Positively \\
\hline
\end{tabular}

\section{REFERENCES}

Aagaard, Kaare. 2012. Reformbølgen Tager Form. In Dansk forskningspolitik efter årtusindeskiftet, ed. K. Aagard and N. Mejlgaard, 37-57. Aarhus: Aarhus Universitetsforlag.

Aagaard, Kaare., Hanne Foss Hansen, and Jørgen Gulddahl Rasmussen. 2016. Mergers in Danish Higher Education: An Overview Over the Changing Landscape. In Mergers in Higher Education: The Experience from Northern Europe, ed. Rómulo Pinheiro, Lars Geschwind, and Timo Aarrevaara, 73-88. Heidelberg: Springer.

Act. 2005. Act Relating to Universities and University Colleges. Oslo: Ministry of Education and Research. www.regjeringen.no/no/dep/kd/. 
Benner, Mats. 2008. Kunskapsnation i kris? Politik, pengar och makt in svensk forskning. Lund: Nya Doxa.

Bleiklie, Ivar., Roar Høstaker, and Agnete Vabø. 2000. Policy and Practices in Higher Education: Reforming Norwegian Universities. London: JessicaKingsley Publishers.

Dahler-Larsen, Peter 2012. Betydningen af bibliometriske indikatorer. In Hvordan styres videnssamfundet? Demokrati, ledelse og organisering, ed. Jan Faye and David Budtz Pedersen. København, 337-357. Frederiksberg: Nyt fra Samfundsvidenskaberne.

Danske Universiteter. 2013. Tal om de danske universiteter. Copenhagen: Danske Universiteter.

DBH-NSB. Database for Statistics on Norwegian Higher Education. https://dbh. nsd.uib.no/.

Geschwind, Lars. 2017. Higher Education Systems and Institutions, Sweden. In Encyclopedia of International Higher Education Systems and Institutions, ed. Jung Cheol Shin and Pedro Nuno Teixeira. Dordrecht: Springer.

Gornitzka, Åse and Liv Langfeldt. 2008. Borderless Knowledge: Understanding the "New" Internationalisation of Research and Higher Education in Norway. Dordrecht: Springer.

Hansen, Hanne Foss. 2001. Forskningspolitik i vidensamfundet: Styrker og svagheder i Forskningskommissionens betænkning. Samfundsøkonomen (8): 11-18.

Kivistö, Jussi and Elias Pekkola. 2013. Qualitative Data Finland. Unpublished Background Report for Orr, D., Wespel, J., and Usher, A. 2014. Do Changes in Cost-Sharing Have an Impact on the Behaviour of Students and Higher Education Institutions? Evidence from Nine Case Studies. Volume II: National Reports. Brussels: European Commission.

Kyvik, Svein. 2009. The Dynamics of Change in Higher Education: Expansion and Contraction in an Organisational Field. Dordrecht: Springer.

Kyvik, Svein and Bjørn Stensaker. 2013. Factors Affecting the Decision to Merge: The Case of Strategic Mergers in Norwegian Higher Education. Tertiary Education and Management 19 (4): 323-337. https://doi.org/10.1080/135 83883.2013.805424.

Langfeldt, Liv, Siri Borlaug, Dag Aksnes, Mats Benner, Hanne Foss Hansen, Egil Kallerud, Ernst Kristiansen, Anti Pelkonen, and Gunnar Sivertsen. 2013. Excellence Initiatives in Nordic Research Policies: Policy Issues - Tensions and Options. NIFU Working Paper 10/2013, Oslo.

Melin, Goran; Zuijdam, Frank; Good, Barbara; Angelis, Jelena; Enberg, Johanna; Fikkers, Derek Jan; Puukka, Jaana; Swenning, AnnaKarin; Kosk, Kristel; Lastunen, Jesse; Zegel, Stijn. 2015. Towards a Future Proof System for Higher Education and Research in Finland. Report of the Ministry of Education and Culture, Finland 2015:11, Ministry of Education and Culture, Helsinki.

Michelsen, Svein and Peter Åmodt. 2006. Kvalitetsreformen moter virkeligheten. Delrapport 1 [The Quality Reform Meets Reality. Evaluation Report 1]. Oslo: Norsk forskningsråd. 
Ministry of Education. 2005. OECD Thematic Review of Tertiary Education: Country Background Report for Norway. Oslo: The Norwegian Ministry of Education and Research.

Ministry of Science, Technology and Innovation. 2009. The University Evaluation 2009. Evaluation Report, Copenhagen, p. 105.

Pekkola, Elias and Jussi Kivistö. 2012. Reforming the Finnish University System: Policies and Institutional Responses. In Leadership and Governance in Higher Education: Handbook for Decision-Makers and Administrators, ed. Bergan Sjur, Eva Egron-Polak, Jürgen Kohler, Lewis Purser, and Martina Vukasović, 87-105. Berlin: Raabe.

Pinheiro, Rómulo., Lars Geschwind, and Timo Aarrevaara, eds. 2016. Mergers in Higher Education: The Experience from Northern Europe. Vol. 46. Cham/ Heidelberg/New York/Dordrecht and London: Springer.

Pinheiro, Rómulo and Bjørn Stensaker. 2018. Balancing Efficiency and Equity in a Welfare State Setting: High Participation Higher Education in Norway. In High Participation Systems of Higher Education, ed. Brendan Cantwell, Simon Marginson, and Anna Smolentseva, 386-417. Oxford: Oxford University Press. Regeringen. 2010. SU, der skaber vakst og beskaftigelse. Bedre brug af SU-midlerne. Copenhagen: Regeringen.

Research Commission. 2001. The Research Commission's Report, B 1 and 2. Report No. 1406, Research Commission, Copenhagen.

Schneider, Jesper and Kare Aagaard. 2012. Stor ståhej for ingenting. Den danske bibliometriske indicator. In Dansk forskningspolitik efter årtusindeskiftet, ed. Kare Aagaard and Nils Mejlgaard, 229-260. Aarhus: Aarhus Universitetsforlag. Skodvin, Ole-Jacob, and Stein Erik Lid. 2018. Governance Tools to Increase Quality and Diversity in Higher Education: Emerging Trends in Norway. In Quality, Performance and Accountability in Higher Education, ed. E. Hazelkorn, H. Coates, and A. McCormick, 487-497. Cheltenham and Northampton: Edward Elgar.

St. Meld. 16 (2016-2017). Kultur for kvalitet $i$ hoyere utdanning: Melding til Stortinget. Oslo: Det Kongelige Kunnskapsdepartementet. Online. https:// www.regjeringen.no/no/dokumenter/meld.-st.-16-20162017/id2536007/.

St. Meld. 27 (2000-2001). Gjor din plikt - Krev din rett: Kvalitetsreform av høyere utdanning. Oslo: Det Kongelige Kirke-, utdannings- og forskningsdepartementet. Online. https://www.regjeringen.no/no/dokumenter/stmeldnr-27-2000-2001-/id194247/.

Statistics Finland. Online. https://www.stat.fi/index_en.html.

Statistics from Universities Denmark. Online. https://dkuni.dk/tal-og-fakta/ beredskab/.

Stensaker, Bjørn. 2014. Troublesome Institutional Autonomy: Governance and the Distribution of Authority in Norwegian Universities. In International Trends in University Governance: Autonomy, Self-Government and the Distribution of Authority, ed. Michael Shattock, 34-48. New York: Routledge. 
Strut 2019. U 2017:05 Styrning för starka och ansvarsfulla lärosäten. http:// www.sou.gov.se/utredningen-om-styrning-for-starka-och-ansvarsfullalarosaten/.

Swedish Govt. Bill 2000/2001. Swedish Government. 2000. Forskning och förnyelse (Research and Renewal), Prop, 3. Vol. 01. Stockholm: Ministry of Education.

Swedish Govt. Bill 2004/2005. Swedish Government. 2005. Forskning för ett bättre liv (Research for a Better Life), Prop, 80. Vol. 05. Stockholm: Ministry of Education.

Swedish Govt. Bill 2008/2009. Swedish Government. 2008. Ett lyft för forskning och innovation (A Boost for Research and Innovation), Prop, 50. Vol. 09. Stockholm: Ministry of Education.

Swedish Govt. Bill 2009/2010:80. En reformerad konstitution (A Reformed Constitution). Stockholm: Ministry of Education.

Swedish Govt. Bill 2012/2013. Swedish Government. 2012. Forskning och innovation (Research and Innovation), Prop, 30. Vol. 13. Stockholm: Ministry of Education.

The Ministry of Education and Culture. https://minedu.fi/en/frontpage.

UKÄ. Swedish Higher Education Authority. http://english.uka.se/.

Universities Act, 165/1997. Finnish Ministry of Education and Culture. Accessed September 27, 2018. https://www.finlex.fi/fi/laki/kaannokset/1997/ en19970645.pdf.

Universities Act, 558/2009. Finnish Ministry of Education and Culture. Accessed September 27, 2018. https://www.finlex.fi/en/laki/kaannokset/2009/ en20090558.

Open Access This chapter is licensed under the terms of the Creative Commons Attribution 4.0 International License (http://creativecommons.org/licenses/ by $/ 4.0 /$ ), which permits use, sharing, adaptation, distribution and reproduction in any medium or format, as long as you give appropriate credit to the original author(s) and the source, provide a link to the Creative Commons licence and indicate if changes were made.

The images or other third party material in this chapter are included in the chapter's Creative Commons licence, unless indicated otherwise in a credit line to the material. If material is not included in the chapter's Creative Commons licence and your intended use is not permitted by statutory regulation or exceeds the permitted use, you will need to obtain permission directly from the copyright holder.

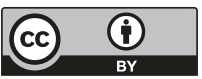

